\title{
Differential Subcellular Localization of mGluR1a and mGluR5 in the Rat and Monkey Substantia Nigra
}

\author{
George W. Hubert, Maryse Paquet, and Yoland Smith \\ Yerkes Regional Primate Research Center, Division of Neuroscience and Department of Neurology, Emory University, \\ Atlanta, Georgia 30322
}

Neurons in the rat substantia nigra (SN) are enriched in group I metabotropic glutamate receptor (mGluR) subtypes and respond to group I mGluR activation. To better understand the mechanisms by which mGluR1 and mGluR5 mediate these effects, the goal of this study was to elucidate the subsynaptic localization of these two receptor subtypes in the rat and monkey substantia nigra. At the light microscope level, neurons of the $\mathrm{SN}$ pars reticulata $(\mathrm{SNr})$ displayed moderate to strong immunoreactivity for both mGluR1a and mGluR5 in rats and monkeys. However, mGluR1a labeling was much stronger in monkey than in rat SN pars compacta (SNc) neurons, whereas a moderate level of mGluR5 immunoreactivity was found in both species. At the electron microscope level, the immunoreactivity for both group I mGluR subtypes was primarily expressed postsynaptically, although light mGluR1a labeling was occasionally seen in axon terminals in the rat SNr. Immunogold studies revealed a striking difference in the subcellular distribution of mGluR1a and mGluR5 immunoreactivity in SNr and SNc neurons. Although the bulk of mGluR1a was attached to the plasma membrane, $>80 \%$ of mGluR5 immunoreactivity was intracellular. Plasma membrane-bound immunoreactivity for group I mGluRs in both SNc and SNr neurons was mostly extrasynaptic or in the main body of symmetric, putative GABAergic synapses. On the other hand, asymmetric synapses either were nonimmunoreactive or displayed perisynaptic labeling. These data raise important questions about the trafficking, internalization, and potential functions of group I mGluRs at extrasynaptic sites or symmetric synapses in the substantia nigra.

Key words: metabotropic; glutamate; receptor internalization; receptor trafficking; dopamine neurons; Parkinson's disease; immunogold method
The substantia nigra pars reticulata $(\mathrm{SNr})$ and the internal segment of the globus pallidus are the main output nuclei of the basal ganglia, whereas the $\mathrm{SN}$ pars compacta $(\mathrm{SNc})$ is a group of dopaminergic neurons that project to the striatum. Both the $\mathrm{SNr}$ and $\mathrm{SNc}$ receive glutamatergic innervation from the subthalamic nucleus), cerebral cortex, and pedunculopontine tegmental nucleus (Wichmann and DeLong, 1998).

The effects of glutamate in the CNS are mediated by activation of ionotropic and metabotropic receptors. Ionotropic receptors are ligand-gated cation channels that mediate fast excitatory neurotransmission, whereas metabotropic glutamate receptors (mGluRs) belong to a family of G-protein-coupled receptors that mediate modulatory effects of synaptic transmission by activation of a number of intracellular metabolic pathways. The family of mGluRs is subdivided into three groups (Conn and Pin, 1997). The group I mGluRs consist of mGluR1, mGluR5, and all their splice variants. These receptors are coupled to phosphoinositol hydrolysis and usually induce slow depolarization. On the other hand, group II (mGluR2,3) and group III (mGluR4,6,7,8) mGluRs are negatively coupled to adenylate cyclase and often induce presynaptic inhibition of transmitter release. Electron microscopic studies revealed that group I mGluRs are located

\footnotetext{
Received Sept. 29, 2000; revised Dec. 8, 2000; accepted Dec. 22, 2000.

This work was supported by National Institutes of Health Grants R01 NS37423-03, P50 NS38399-01, and RR 00165, and a grant from the American Parkinson's Disease Association. We acknowledge Jean-François Paré for technical assistance and Frank Kiernan for photography.

Correspondence should be addressed to Yoland Smith, Yerkes Regional Primate Research Center, Emory University, 954 Gatewood Road NE, Atlanta, GA 30322. E-mail: yolands@rmy.emory.edu.

Copyright (C) 2001 Society for Neuroscience $0270-6474 / 01 / 211838-10 \$ 15.00 / 0$
}

perisynaptically to the postsynaptic specializations of asymmetric glutamatergic synapses in the hippocampus and cerebellum in the rat (Baude et al., 1993; Nusser et al., 1994; Lujan et al., 1996; Ottersen and Landsend, 1997) and various basal ganglia structures in monkeys (Hanson and Smith, 1999; Smith et al., 2000). However, we recently demonstrated that group I mGluRs are also associated with the active zones of GABAergic striatopallidal synapses in the monkey (Hanson and Smith, 1999), which raises interesting questions about the functions and mechanisms of activation of group I mGluRs in the primate basal ganglia. Obviously, the localization of a receptor relative to its source of activation might have a significant effect on the transduction of the glutamatergic signal by a number of means. For instance, the proximity of mGluRs to other receptor subtypes may affect the response of these receptors to synaptic activation via various mechanisms, including activation of common second-messenger systems (Greengard et al., 1999), modulation of membrane excitability (Conn and Pin, 1997), or direct protein-protein interactions (Liu et al., 2000).

Group I mGluR mRNA and the receptor proteins are expressed in rat $\mathrm{SNc}$ and $\mathrm{SNr}$ neurons (Berthele et al., 1998; Kosinski et al., 1998; Testa et al., 1994, 1998). Furthermore, electrophysiological studies have demonstrated that metabotropic glutamatergic stimulation has myriad effects on the firing rate and firing pattern of neurons in both portions of the SN (Meltzer et al., 1997; Fiorello and Williams, 1998; Wigmore and Lacey, 1998; Marino et al., 1999). To better understand the synaptic mechanisms by which mGluRs mediate these effects, the goal of the present study was to characterize the subsynaptic localization of Group I mGluRs in the rat and monkey SN. 
Data presented in this study have been published previously in abstract form (Hubert and Smith, 1999).

\section{MATERIALS AND METHODS}

\section{Animals and tissue preparation}

Twenty Sprague Dawley rats and five adult Rhesus monkeys were deeply anesthetized with pentobarbital (100 mg/kg, i.v., for monkeys) or a mixture of ketamine $(100 \mathrm{mg} / \mathrm{kg}$, i.p., for monkeys) and dormitor $(0.1$ $\mathrm{mg} / \mathrm{kg}$, i.p., for rats) and transcardially perfused with $100-300 \mathrm{ml}$ of cold, oxygenated Ringer's solution. This was followed by $500-1000 \mathrm{ml}$ of fixative containing $4.0 \%$ paraformaldehyde and $0.1-0.75 \%$ glutaraldehyde dissolved in phosphate buffer (PB; $0.1 \mathrm{M}, \mathrm{pH}$ 7.4). Free aldehydes were then washed from the brains by perfusion with $500 \mathrm{ml}$ of cold PB. Brains were removed from the skull, cut in 10-mm-thick slabs, and stored in PBS $(0.01 \mathrm{M}, \mathrm{pH} 7.4)$ overnight at $4^{\circ} \mathrm{C}$. The brains were then cut into $60-\mu \mathrm{m}$-thick coronal sections on a vibrating microtome. Sections were put in a $1.0 \%$ sodium borohydride solution, dissolved in PBS for $20 \mathrm{~min}$, and rinsed with PBS before being processed for immunocytochemistry. The anesthesia and euthanasia procedures were performed according to the National Institutes of Health Guidelines and have been accepted by the Institutional Animal Care and Use Committee of Emory University. All efforts were made to reduce the number of animals used and minimize animal suffering.

\section{Immunoperoxidase localization of mGluR1a and mGluR5}

Primary antisera. Two commercially available affinity-purified rabbit polyclonal antibodies raised against synthetic C-terminus peptides representing different amino acid sequences of mGluR1a (PNVTYASVILRDYKQSSSTL; Chemicon, Temecula, CA) and mGluR5a/b (KSSPKYDTLIIRDYTNSSSSL; Upstate Biotechnology, Lake Placid, NY) were used in this study. In immunoblot analysis of rat brain microsomes or rabbit brain extracts, both antibodies labeled a single band with an estimated molecular weight of $145 \mathrm{kDA}$, which corresponds to that of mGluR1a and mGluR5 proteins (Houamed et al., 1991; Abe et al., 1992; Minakami et al., 1993; Testa et al., 1998).

Light microscope procedures. The sections were preincubated in a solution containing $10 \%$ normal goat serum (NGS), $1.0 \%$ bovine serum albumin (BSA), and $0.3 \%$ Triton X-100 in PBS for $1 \mathrm{hr}$. They were then incubated overnight with primary antisera diluted at $0.5-1.0 \mu \mathrm{g} / \mathrm{ml}$ in a solution containing $1.0 \%$ NGS, $1.0 \%$ BSA, and $0.3 \%$ Triton X-100 in PBS. Next, the sections were rinsed in PBS and transferred for $1 \mathrm{hr}$ to a secondary antibody solution containing biotinylated goat anti-rabbit IgGs (Vector Laboratories, Burlingame, CA) diluted 1:200 in the primary antibody diluent solution. After rinsing, sections were put in a solution containing 1:100 avidin-biotin-peroxidase complex (Vector). The tissue was then washed in PBS and $0.05 \mathrm{~m}$ Tris buffer before being transferred to a solution containing $0.01 \mathrm{~m}$ imidazole, $0.0005 \%$ hydrogen peroxide, and $0.025 \% 3,3^{\prime}$-diaminobenzidine tetrahydrochloride (Sigma, St. Louis, MO) in Tris for 7-10 min. Sections were then mounted on gelatin-coated slides and dried, and a coverslip was applied with Permount.

Electron microscope procedures. After vibratome cutting, sections were transferred to a cryoprotectant solution ( $\mathrm{PB}, 0.05 \mathrm{M}, \mathrm{pH} 7.4$, containing $25 \%$ sucrose and $10 \%$ glycerol) for $20 \mathrm{~min}$. They were then frozen in a $-80^{\circ} \mathrm{C}$ freezer for $20 \mathrm{~min}$, returned to a decreasing gradient of cryoprotectant solutions, and rinsed in PBS. Sections underwent immunocytochemical procedures for the immunoperoxidase localization of mGluR1a and mGluR5 in a manner identical to that for the light microscope, except that the incubation in the primary antisera was performed at $4^{\circ} \mathrm{C}$ for $48 \mathrm{hr}$ and Triton X-100 was omitted from all incubation solutions.

The sections were transferred to $\mathrm{PB}(0.1 \mathrm{M}, \mathrm{pH} 7.4)$ for $10 \mathrm{~min}$ and exposed to $1 \%$ osmium tetroxide for $20 \mathrm{~min}$. They were then rinsed with $\mathrm{PB}$ and dehydrated in an increasing gradient of ethanol. Uranyl acetate (1\%) was added to the $70 \%$ alcohol to increase contrast at the electron microscope. The sections were then treated with propylene oxide before being embedded in epoxy resin (Durcupan, ACM; Fluka, Buchs, Switzerland) for $12 \mathrm{hr}$, mounted on microscope slides, and placed in a $60^{\circ} \mathrm{C}$ oven for $48 \mathrm{hr}$.

Pieces of SNc and SNr tissue were taken out from the slides and glued on the top of resin blocks with cyanoacrylate glue. They were cut into 60 $\mathrm{nm}$ ultrathin sections with an ultramicrotome (Ultracut T2; Leica, Nussloch, Germany) and serially collected on single-slot Pioloform-coated copper grids. The sections were stained with lead citrate for $5 \mathrm{~min}$ (Reynolds, 1963) and examined with a Zeiss EM-10C electron microscope (Thornwood, NY).
Table 1. Summary of material used for the immunogold localization of mGluR1a and mGluR5 in the substantia nigra of rat and monkey

\begin{tabular}{llllc} 
Species & Structure & Receptors & $\begin{array}{l}\text { Number of } \\
\text { blocks }\end{array}$ & $\begin{array}{l}\text { Surface of } \\
\text { tissue }\left(\mu \mathrm{m}^{2}\right)\end{array}$ \\
\hline Rat & SNr & mGluR1a & 4 & 1451 \\
Rat & $\mathrm{SNr}$ & mGluR5 & 4 & 888 \\
Monkey & $\mathrm{SNr}$ & mGluR1a & 2 & 2764 \\
Monkey & $\mathrm{SNr}$ & mGluR5 & 2 & 3262 \\
Monkey & $\mathrm{SNc}$ & mGluR1a & 3 & 5975 \\
Monkey & $\mathrm{SNc}$ & mGluR5 & 4 & 4258 \\
\hline
\end{tabular}

\section{Immunogold localization of mGluR1a and mGluR5}

Sections processed for pre-embedding immunogold were transferred to the cryoprotectant solution and frozen at $-80^{\circ} \mathrm{C}$ in the same way as those processed for immunoperoxidase. They were then preincubated for $1 \mathrm{hr}$ in a solution containing $10 \%$ NGS in PBS-BSA $(0.005 \%$ BSA, $0.05 \%$ Tween 20 , and $0.001 \%$ gelatin in PBS) before being transferred to a $1 \%$ NGS in PBS-BSA solution containing the primary antibodies for either mGluR1a $(0.5 \mu \mathrm{g} / \mathrm{ml})$ or mGluR5 $(1.0 \mu \mathrm{g} / \mathrm{ml})$ for $48 \mathrm{hr}$ at $4^{\circ} \mathrm{C}$. Next, they were rinsed in PBS-BSA and incubated for $2 \mathrm{hr}$ in the secondary $1.4 \mathrm{~nm}$ gold-conjugated goat anti-rabbit IgGs (Nanogold; Nanoprobes, Stonybrook, NY) at a concentration of 1:100 in 1\% NGS in PBS-BSA. The sections were then fixed overnight in $1-2 \%$ glutaraldehyde and rinsed with PB before the silver intensification of gold particles for 5-10 min using the HQ silver kit (Nanoprobes). Next, they were rinsed with PB, treated with osmium tetroxide $(1.0 \%$ in $\mathrm{PB}, 0.1 \mathrm{M}, \mathrm{pH} 7.4)$ for $20 \mathrm{~min}$, and dehydrated in a graded series of alcohol and propylene oxide. The remainder of the procedure was the same as that described above for the immunoperoxidase material.

\section{Control experiments}

For both immunoperoxidase and immunogold reactions, controls included sections of $\mathrm{SN}$ incubated in solutions in which the primary antisera were replaced by $1 \%$ nonimmune rabbit serum; the rest of the procedure remained the same as described above. Sections processed in this way were totally devoid of immunoperoxidase deposit or gold particles at the electron microscope level.

\section{Analysis of material}

Immunoperoxidase material. A total of 14 blocks from rat and monkey $\mathrm{SNr}$ [4 (2 for mGluR1a, 2 for mGluR5) from rat, 3 (2 for mGluR1a, 1 for mGluR5) from monkey] and SNc [7 (6 for mGluR1a, 1 for mGluR5) from monkey] were cut out from the slides, mounted on resin blocks, and glued into place using cyanoacrylate glue. In both rats and monkeys, all blocks were collected from the mid rostrocaudal level of the substantia nigra (bregma $-5.6 \mathrm{~mm}$ in rat) where the $\mathrm{SNc}$ and $\mathrm{SNr}$ are clearly separate. The SNc blocks were taken from the dense cluster of dopaminergic neurons in the dorsomedial part of the SN, whereas SNr blocks were collected from the ventral part of the SN along the cerebral peduncle. Ultrathin sections were scanned for the presence of immunoperoxidase-labeled structures that were easily distinguishable from unlabeled elements by their electron-dense reaction product. Lowpower $(10,000 \times)$ and high-power $(<20,000 \times)$ electron micrographs of randomly selected immunoreactive elements were taken for analysis. Immunoreactive elements were categorized as presynaptic (axons, terminals) or postsynaptic (perikarya, dendrites, spines) neuronal structures or glial cells on the basis of ultrastructural features.

Immunogold material. A total of 19 blocks (Table 1) from rat and monkey $\mathrm{SNr}$ and $\mathrm{SNc}$ were cut out from the slides, mounted on resin blocks, and glued into place using cyanoacrylate glue. Blocks were collected in the same regions of $\mathrm{SNc}$ and $\mathrm{SNr}$ as those taken for immunoperoxidase observations (see above). Ultrathin sections from the surface of the blocks were examined under the electron microscope, and randomly selected elements containing gold particles were photographed at low $(10,000 \times)$ and high $(\geq 20,000 \times)$ magnifications. Low-power micrographs were taken to determine the overall distribution of immunogold particles, whereas high-power micrographs were used to determine the relationship of immunoreactivity to specific synaptic contacts. Immunogold particles were designated as membrane-bound if they were in 

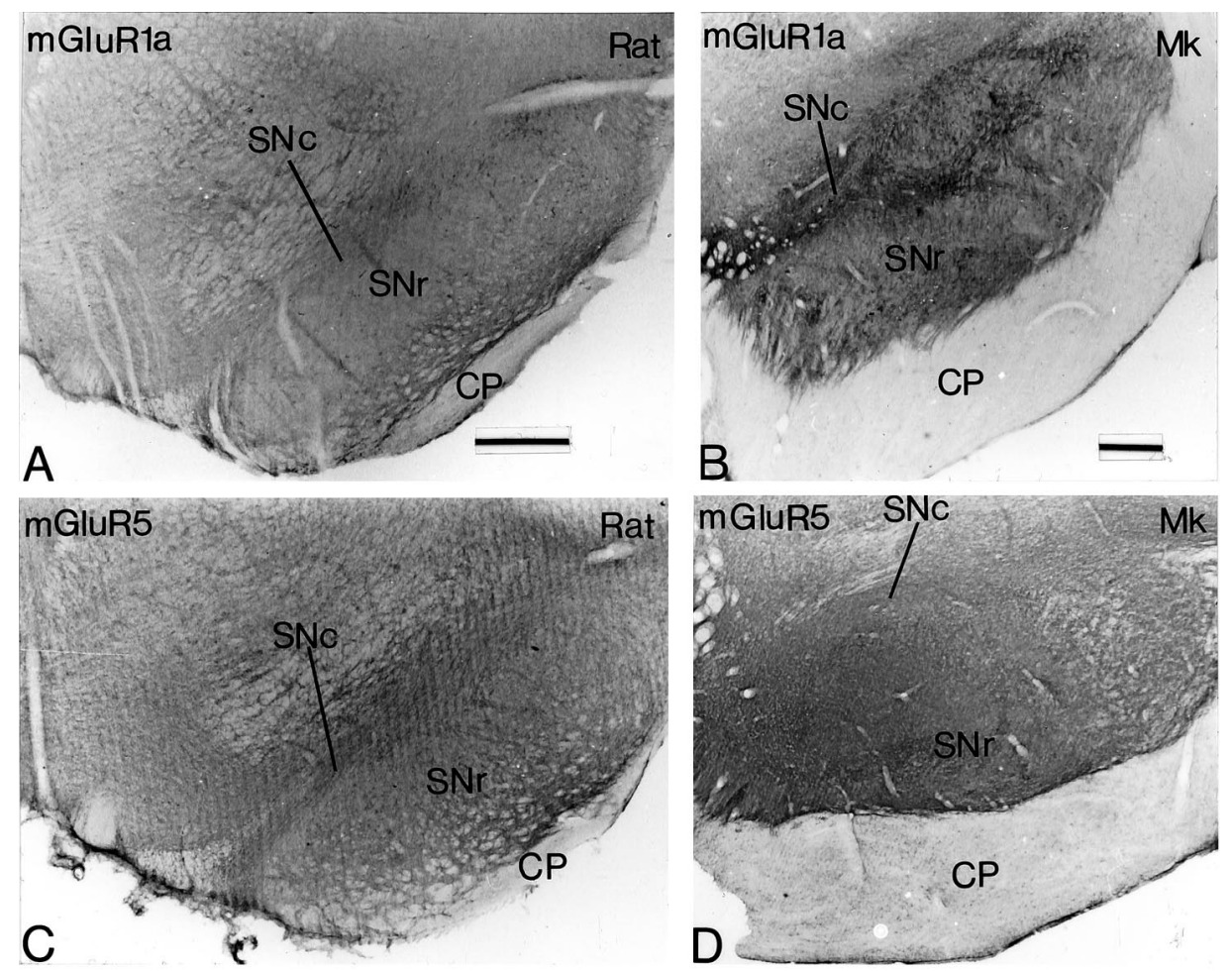

Figure 1. Light microscope examination of Group I mGluR distribution in the right ventral midbrain of rat and monkey using the immunoperoxidase method. $A$, Low-power micrograph of mGluR1a in the rat. $B$, Low-power micrograph of mGluR1a in the monkey. $C$, Low-power examination of mGluR5 in the rat. $D$, Low-power micrograph of mGluR5 in the monkey. In $A-D$, medial is on the left, and dorsal is on the top of each micrograph. E, High-power micrograph of mGluR5 in the ventrolateral part of $\mathrm{SNr}$ in the rat. $F$, High-power micrograph of mGluR1a-immunoreactive dendrites of $\mathrm{SNc}$ neurons descending into the $\mathrm{SNr}$. $C P$, Cerebral peduncle; $M k$, monkey. Scale bars: $A, 500 \mu \mathrm{m}$ (valid for $C) ; B, 500$ $\mu \mathrm{m}$ (valid for $D$ ); $E, 50 \mu \mathrm{m}$ (valid for F).
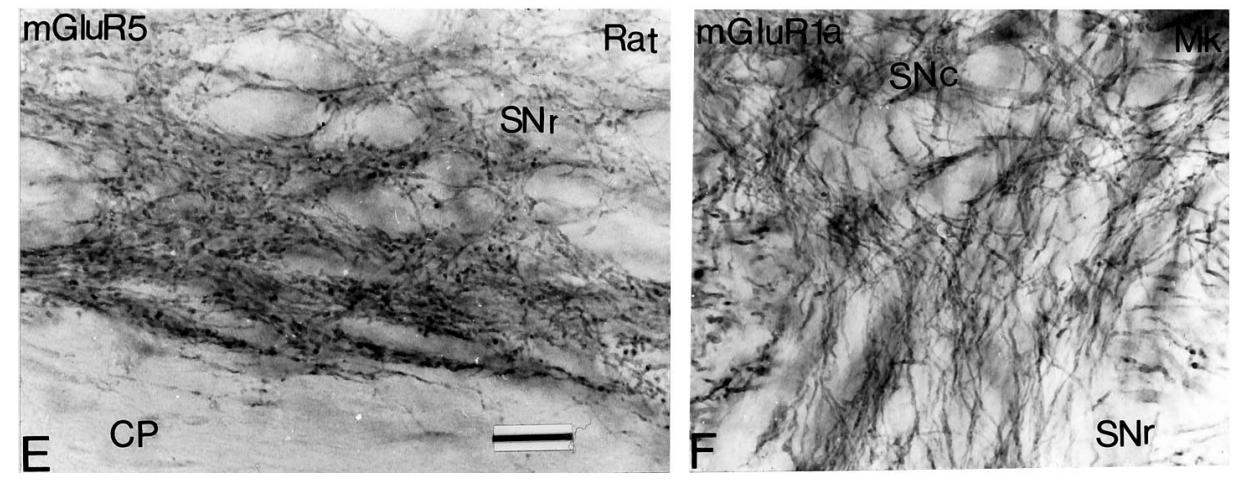

direct contact with the plasma membrane. All other gold particles were categorized as intracellular. On the basis of their localization relative to synapses, membrane-bound immunogold particles were classified into three main categories: (1) extrasynaptic, if they were attached to parts of the plasma membrane not involved in synaptic contacts; (2) perisynaptic, if they were located $<20 \mathrm{~nm}$ away from the edges of symmetric or asymmetric postsynaptic specializations; or (3) synaptic, if they were located in the main body of postsynaptic specializations. Portions of dendrites and cell bodies that were poorly preserved or cut in a plane of a section that was not suitable to distinguish the presynaptic and postsynaptic membranes were not considered in this analysis. To ascertain the specificity of labeling, some immunoreactive synapses were examined in a series of three to five ultrathin sections.

To measure the surface of dendrites and the length of synaptic junctions, micrographs of immunolabeled dendrites taken from the $\mathrm{SNr}$ were scanned with a digital scanner (Powerlook II; Umax, Fremont, CA) and analyzed for total dendritic membrane length and total length of synaptic active zones using a Neurolucida setup and Morph software (MicroBrightField, Colchester, VT).

\section{RESULTS}

\section{Light microscope observations}

At the light microscope level, the pattern of labeling for both mGluR subtypes followed a mediolateral gradient, being heaviest ventrolaterally and progressively lighter dorsomedially (Fig. $1 A, C, E)$. Both antibodies stained neuronal processes more in- tensely than cell bodies. The SNc displayed a light to moderate staining for mGluR1a and mGluR5, respectively (Fig. 1A,C).

In the monkey, the pattern of immunoreactivity for mGluR5 resembled that in the rat (Fig. $1 D)$. In contrast, the antibody for mGluR1a strongly labeled both SNc and SNr neurons (Fig. 1B). As in the rat, neuronal processes were preferentially labeled over cell bodies. High-power light microscope examination of the SNc showed intensely labeled mGluR1a-containing dendrites of SNc neurons descending into the SNr (Fig. 1F).

\section{Electron microscope observations Immunoperoxidase labeling}

Blocks of SNc and SNr immunostained for mGluR1a or mGluR5 were examined at the electron microscope level, and immunoreactive elements were categorized according to their ultrastructural features. Although blocks from the SNr were collected from the ventral part of the SN (see Materials and Methods), they also contained dopaminergic dendrites from neurons in the ventral tier of the SNc that travel dorsoventrally throughout the SN (Fig. $1 F)$. Because of technical limitations in combining mGluR immunostaining with tyrosine hydroxylase labeling, we could not use any marker to differentiate dopaminergic from nondopaminergic elements in this study. However, on the basis of previous 

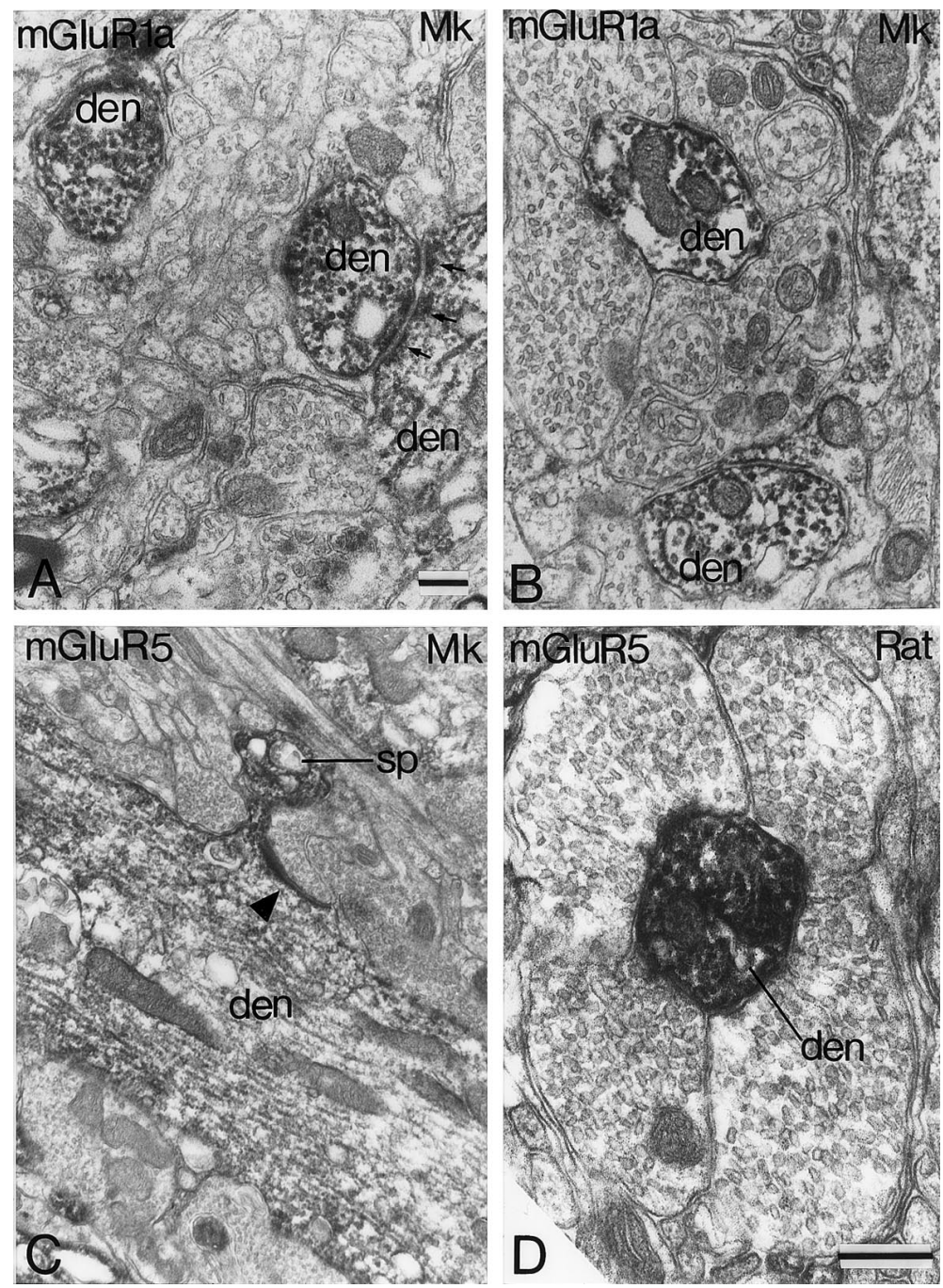

Figure 2. Electron microscope examination of group I mGluR immunoperoxidase labeling in the ventral midbrain. $A$, mGluR1a-immunoreactive (IR) dendrites (den) in the monkey SNc. Note the apposition between the two immunoreactive dendrites (arrows). B, mGluRla-IR dendrite in the monkey $\mathrm{SNr}$. Note the different pattern of innervation of SNc and $\mathrm{SNr}$ dendrites $(A, B)$. $C$, An mGluR5-containing dendrite and spine $(s p)$ in the monkey SNc. Note the dense peroxidase deposit at the axodendritic synapse (arrowhead). D, An mGluR5containing dendrite in the rat SNr. $M k$, Monkey. Scale bars: $A$, $0.25 \mu \mathrm{m}$ (valid for $B, C) ; D, 0.25 \mu \mathrm{m}$. findings, we used ultrastructural criteria to categorize dendrites as belonging to $\mathrm{SNr}$ or SNc neurons. Indeed, it is well established that neurons in the $\mathrm{SNr}$ are tightly surrounded by striatal GABAergic terminals that display a very particular rosette-like pattern of dendritic innervation (Grofova and Rinvik, 1970; Hajdu et al., 1973; Smith and Bolam, 1991; Smith et al., 1998) (Fig. $2 B, D)$. On the other hand, dendrites of SNc neurons are innervated much less by striatal terminals and often are devoid of synaptic contacts (Bolam and Smith, 1990; Smith et al., 1996) (Fig. $2 A, C$ ). In the following account, the characterization of SNc and $\mathrm{SNr}$ dendrites was therefore based on these ultrastructural features. Dendrites that could not be categorized as $\mathrm{SNc}$ or $\mathrm{SNr}$ elements on the basis of these criteria were omitted from the study.

In keeping with light microscope observations, immunostaining for both mGluR1a and mGluR5 was confined mainly to postsynaptic elements, including dendritic processes and spine-like structures in the monkey $\mathrm{SNc}$ (Fig. $2 A, C$ ) as well as in the rat and monkey $\mathrm{SNr}$ (Fig. $2 B, D$ ). In general, the peroxidase deposit was diffuse and did not display any particular relationship with synaptic sites on the plasma membrane (Fig. 2). Occasionally, light mGluR1a immunoreactivity was found in axon terminals and glial processes in both rat and monkey SNr (Marino et al., 1999). As expected on the basis of the light microscopic data, putative dendrites and cell bodies of rat SNc neurons were mostly devoid of mGluR1a immunoreactivity and displayed light mGluR5 labeling.

\section{Immunogold labeling}

The pre-embedding immunogold method was used to determine the subsynaptic location of group I mGluRs. This method offers a higher spatial resolution than the amorphous peroxidase reaction product and allows better characterization of the localization of receptors in relation to synaptic contacts. Because of the low level of labeling for both receptor subtypes in rat $\mathrm{SNc}$ neurons, the immunogold data were only gathered from $\mathrm{SNr}$ elements in rats, whereas both $\mathrm{SNr}$ and $\mathrm{SNc}$ elements were analyzed in monkeys. The most striking finding that characterized the pattern of group I mGluR immunogold labeling in the $\mathrm{SN}$ was the difference in the relative proportion of mGluR1a and mGluR5 labeling bound to the plasma membrane in rat and monkey $\mathrm{SNr}$ neurons (Figs. 3, 4). Although up to two-thirds of mGluR1a immunolabeling was attached to the plasma membrane, $>80 \%$ of mGluR5 labeling was intracellular (Figs. $3 A, B, 4)$. The bulk of intracellular immunogold labeling in perikarya was associated with the endoplasmic reticulum (Fig. 3C), but gold particles were also attached to the nuclear membrane and endosome-like vesicles. In dendrites, gold particles were often attached to microtubules or endosome-like vesicles, but most were associated with unidentified intracellular compartments (Fig. 3B,D). 
Figure 3. Electron micrographs showing the subcellular distribution of mGluR1a $(A, C)$ and mGluR5 $(B, D)$ immunogold labeling in the rat SNr. $A$, Low-power electron micrograph of two mGluR1a-IR dendrites (den). Note that most of the gold particles are on the plasma membrane. $B$, Low-power electron micrograph of mGluR5-positive dendrites. Note that most of the gold particles are intracellular. $C$, High-power electron micrograph of mGluR1a immunoreactivity associated with the endoplasmic reticulum in a neuronal perikaryon. Small arrows indicate immunoreactive gold particles at a symmetric synapse. $D$, High-power electron micrograph of mGluR5 immunoreactivity in a dendrite. $E R$, Endoplasmic reticulum. Scale bars: $A, 0.5 \mu \mathrm{m}$ (valid for $B) ; C, 0.25 \mu \mathrm{m}$ (valid for $D$ ).
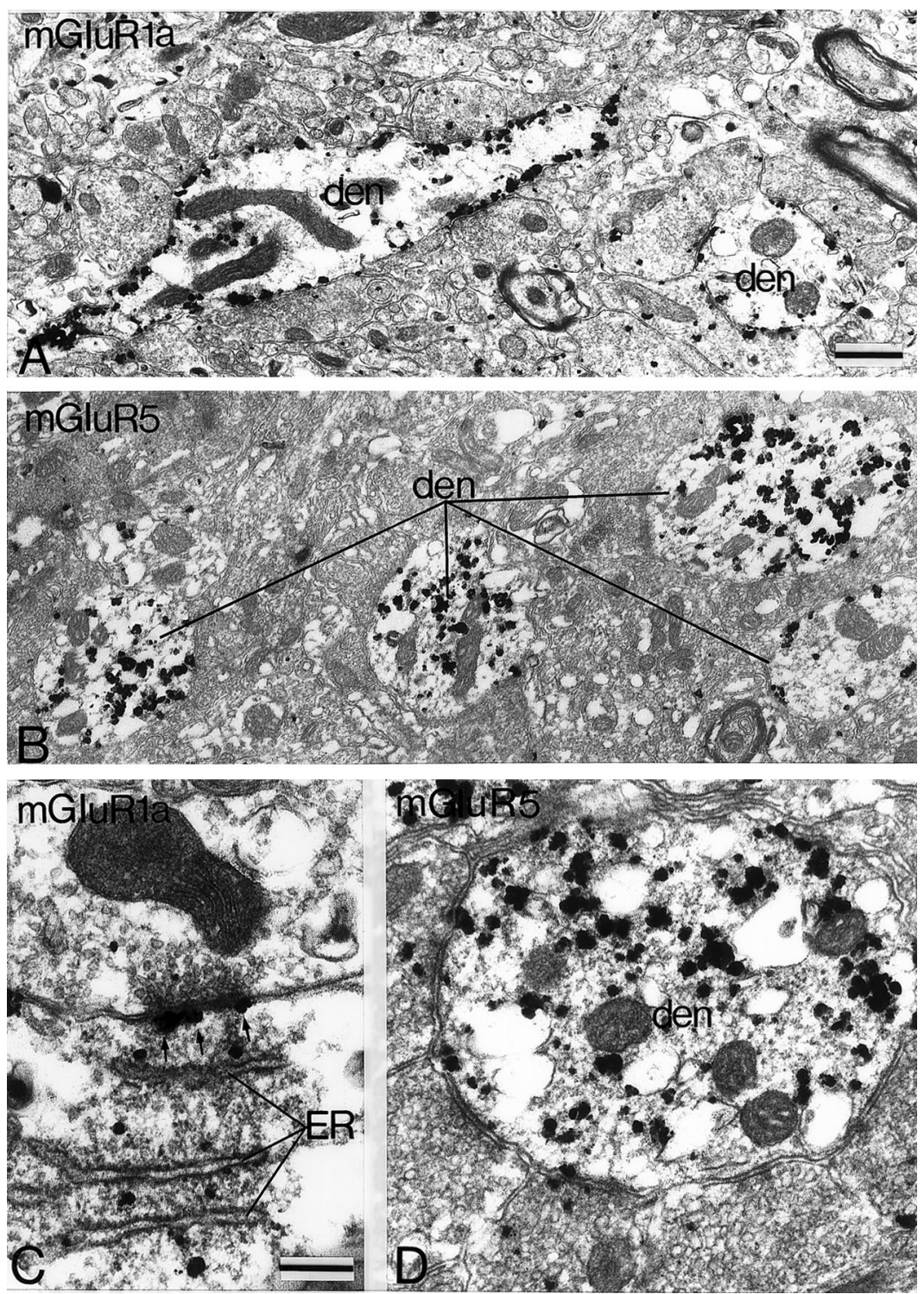

Although the density of gold particles was much lower than in the $\mathrm{SNr}$, significant immunostaining for both mGluR subtypes was found in putative SNc neurons in monkeys (see Fig. 6). Overall, the pattern of labeling in the monkey SNc was the same as in the $\mathrm{SNr}$, i.e., a large proportion of mGluR1a labeling was bound to the plasma membrane, whereas the bulk of mGluR5 immunostaining was localized intracellularly (Fig. 4). However, even the intracellular mGluR1a labeling was slightly higher than the plasma membrane-bound immunoreactivity in the monkey SNc (Fig. 4).

High-power photomicrographs were taken to determine the location of plasma membrane-bound mGluRs in relation to symmetric or asymmetric synaptic junctions in rat and monkey $\mathrm{SNr}$ and in the monkey SNc (Figs. 5, 6). As described above, gold particles attached to the plasma membrane were categorized as extrasynaptic, perisynaptic, or synaptic on the basis of their localization relative to synaptic junctions. A common finding for both compartments of the SN was that most plasma membranebound gold particles were extrasynaptic (Fig. 7 $A, B$ ). Furthermore, as was the case in the monkey pallidum (Hanson and Smith, 1999), a substantial proportion of mGluR1a- and mGluR5- immunoreactive gold particles were expressed in the main body of symmetric synapses established by putative GABAergic striatallike terminals in the rat and monkey $\mathrm{SN}$ (Figs. $5 A-D, F, 6 B, D, 7$ ). To ensure that this labeling was not an artifact of single sections, we followed individual synapses serially and found that the synaptic labeling at symmetric synapses was maintained in at least three to five serial sections (Fig. $5 B, D, F$ ). Because gold particles range from 20 to $40 \mathrm{~nm}$ in diameter (Hanson and Smith, 1999), a single particle cannot be found in more than two sections. Therefore, the fact that the labeling at some synapses was found in at least three sections indicates that multiple gold particles contributed to the immunostaining. Because SNr neurons are tightly surrounded by striatal terminals, one may speculate that the expression of mGluRs at striatonigral synapses merely reflects a random distribution of labeling caused by the high frequency of these synapses. To rule out this possibility, we measured the length of the active zones of synapses on a series of 20 randomly chosen immunoreactive dendrites in the rat $\mathrm{SNr}$ and compared the proportion of dendritic surface occupied by the synaptic contacts with the proportion of plasma membrane-bound gold particles at symmetric synapses. These measurements revealed 


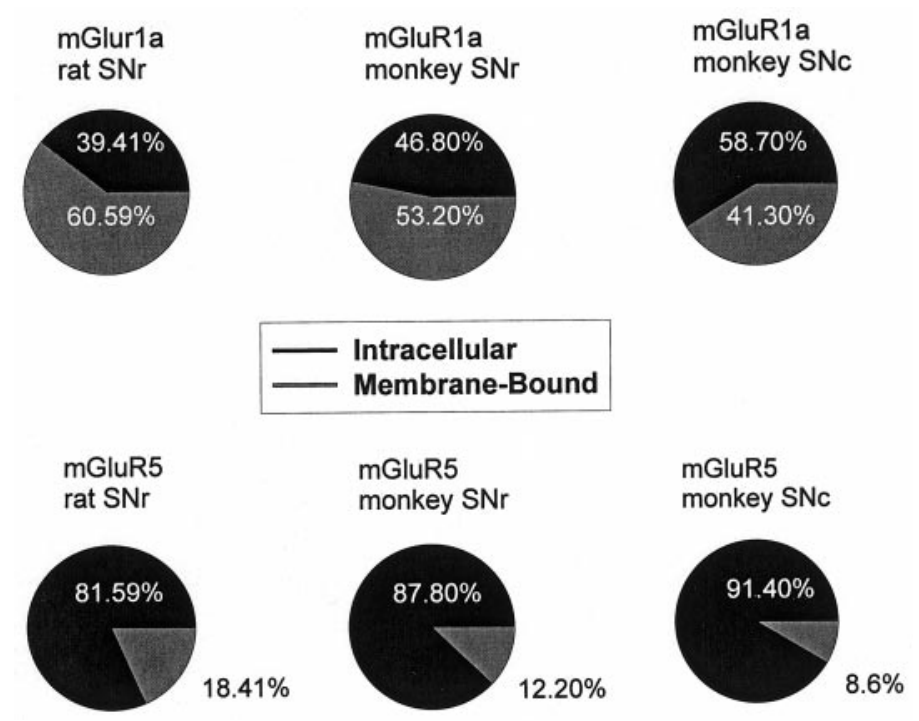

Figure 4. Relative proportion of intracellular versus plasma membranebound immunoreactive gold particles for Group I mGluRs in dendrites of SNr neurons in the rat and monkey and SNc neurons in the monkey. Number of gold particles $(n)$ and dendrites (den) examined: mGluR1a in rat $\mathrm{SNr}(n=306$, den $=20)$; mGluR1a in monkey $\mathrm{SNr}(n=1811$, den $=$ $178)$; mGluR1a in monkey SNc $(n=1566$, den $=230)$; mGluR5 in rat SNr $(n=820$, den $=20)$; mGluR5 in monkey SNr $(n=5350$, den $=200)$; mGluR5 in monkey SNc $(n=9699$, den $=227)$.

that $\sim 70 \%$ of SNr dendritic membrane does not contribute to synaptic contacts, $26 \%$ contributes to symmetric synapses, and $<3 \%$ contributes to asymmetric synapses. Therefore, the proportion of labeling at symmetric synapses (35-45\%) is significantly higher than what would be expected on the basis of a random distribution, which further indicates the specificity of labeling. The remaining plasma membrane-bound gold particles were located perisynaptically to asymmetric synaptic junctions (Figs. $5 E$, $6 A, C, 7)$. None of the asymmetric synapses examined displayed synaptic labeling, which is consistent with previous data on group I mGluRs localization in other brain regions (Ottersen and Landsend, 1997; Hanson and Smith, 1999; Smith et al., 2000)

\section{DISCUSSION}

The results of this study provide the first description of the subsynaptic localization of group I mGluRs in the rat and monkey substantia nigra. Three major conclusions can be drawn from these data. First, mGluR1a immunoreactivity is more strongly expressed in monkey than in rat SNc neurons. Second, the relative proportion of plasma membrane-bound mGluR1a and mGluR5 immunoreactivity is drastically different in rat and monkey SNr. In general, most of the mGluR1a labeling is attached to the plasma membrane, whereas the bulk of mGluR5 immunoreactivity is expressed in intracellular compartments. Finally, plasma membrane-bound group I mGluRs are primarily extrasynaptic or expressed in the main body of symmetric, GABAergic, striatonigral synapses in rats and monkeys. On the other hand, labeling of asymmetric synapses is primarily perisynaptic. These data raise questions about the trafficking and internalization of group I mGluRs as well as the potential functions of these receptors at GABAergic synapses.

\section{Interspecies differences in mGluR1a expression between rats and monkeys}

The mGluR1a antiserum used in this study heavily labeled SNc neurons in monkeys but not in rats, whereas $\mathrm{SNr}$ neurons dis- played moderate to strong labeling in both species. The light mGluR1a labeling in rat SNc neurons is consistent with recent in situ hybridization data showing that the mGluR1a mRNA level is relatively low in rat $\mathrm{SNc}$ neurons that, on the other hand, display strong mRNA expression for the mGluR1d splice variant (Kosinski et al., 1998). It is unlikely that the differential intensity of mGluR1a labeling between the rat and monkey SNc is caused by technical differences in the tissue processing because both species were perfused with the same fixative and incubated with antibodies under similar conditions. Because of technical limitations in quantifying immunoperoxidase deposits, comparative in situ hybridization studies should be performed to further analyze this interspecies difference in mGluR1a expression between rats and primates. It is noteworthy that interspecies differences in the expression of mGluR immunoreactivity are not unique to mGluR1a in the SNc. Recent data showed that the distribution of mGluR2 in various brain regions is different between rats and primates (Phillips et al., 2000). At present, the functional significance of such interspecies differences in the intensity of mGluRs labeling is unknown, but it should be kept in mind while extrapolating data from one species to the other.

\section{Intracellular mGluR5 labeling}

The relative paucity of plasma membrane-bound mGluR5 immunolabeling is surprising. A basal amount of internalized receptors trafficking from their site of synthesis in the cell body to dendrites would be understandable, but such a large proportion of intracellular receptors is rather unusual and strikingly different from mGluR1a, which is mostly expressed on the plasma membrane. It seems that this phenomenon is not unique to group I mGluRs. For instance, the muscarinic receptor $\mathrm{m} 4$ is primarily expressed intracellularly in cholinergic interneurons and projection neurons in the matrix compartment of the rat striatum under basal conditions (Bernard et al., 1999). Similarly, the somatostatin receptor sst2A displays a preferential cytoplasmic localization in neurons that receive dense somatostatin innervation (Dournaud et al., 1998). In general, G-protein-coupled receptors, including mGluR5, become internalized after agonist administration (Mantyh et al., 1995; Bernard et al., 1998, 1999; Dournaud et al., 1998; Dumartin et al., 1998; Lissin et al., 1999; Liu and Kirchgessner, 2000). However, in these conditions, the receptors are initially localized on the plasma membrane in which, presumably, they could be activated by neurotransmitters in the extracellular space. Because most receptors would need to be exposed to the extracellular environment to achieve contact with a signaling molecule, a notable exception being hormone receptors, the mechanism of activation of mGluR5 in $\mathrm{SN}$ neurons is rather puzzling. Recently, it has been shown that a family of proteins called Homer participates in the membrane expression and sequestration of Group I mGluRs (Brakeman et al., 1997). The protein Homer $1 \mathrm{~b}$ has been shown to impede the surface expression of Group I mGluRs, whereas Homer 1a increases the cell surface expression of these receptors (Ciruela et al., 1999; Roche et al., 1999). Although Homer proteins can bind to both group I mGluR subtypes, one may speculate that, in SN neurons, Homer $1 \mathrm{~b}$ has a higher affinity for mGluR5 and sequesters it in the cytoplasm to a higher degree than mGluR1a. Future colocalization studies of Homer proteins and group I mGluRs in SN neurons under basal and various experimental conditions are essential to elucidate this issue.

Another possibility is that some functions necessitate a large intracellular pool of mGluR5 receptors. Although it might take 

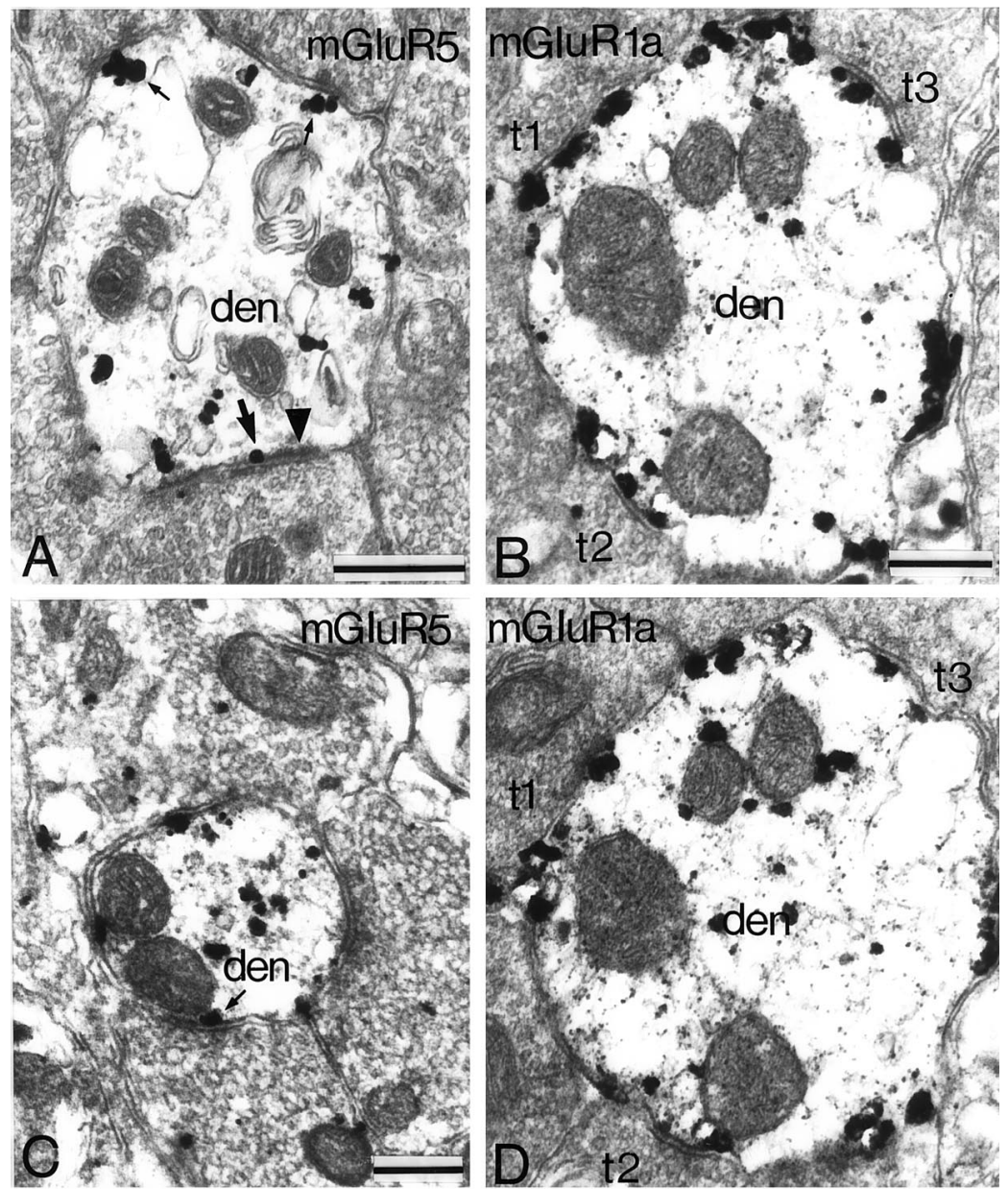

Figure 5. Subsynaptic distribution of Group I mGluRimmunoreactive gold particles in dendrites (den) of $\mathrm{SNr}$ neurons in rat and monkey. $A$, mGluR5 immunoreactivity at symmetric synapses (small arrows) and at an asymmetric synapse (large arrow) in the monkey SNr. The arrowhead indicates the postsynaptic specialization of the asymmetric synaptic contact. $B, D, F$, Serial sections of an mGluR1a-IR dendrite in the rat SNr. Note that the immunoreactivity at symmetric synapses established by three striatal-like terminals $(t 1, t 2, t 3)$ is found in serial sections. $C$, mGluR5 immunoreactivity at a symmetric synapse in the rat SNr (small arrows). E, mGluR1a immunoreactivity (arrow) at the edge of an asymmetric axodendritic synapse (arrowhead) in the rat SNr. Scale bars: $A, 0.25 \mu \mathrm{m} ; B$, $0.25 \mu \mathrm{m}$ (valid for $D, F$ ); $C, 0.25 \mu \mathrm{m}$ (valid for $E$ ).
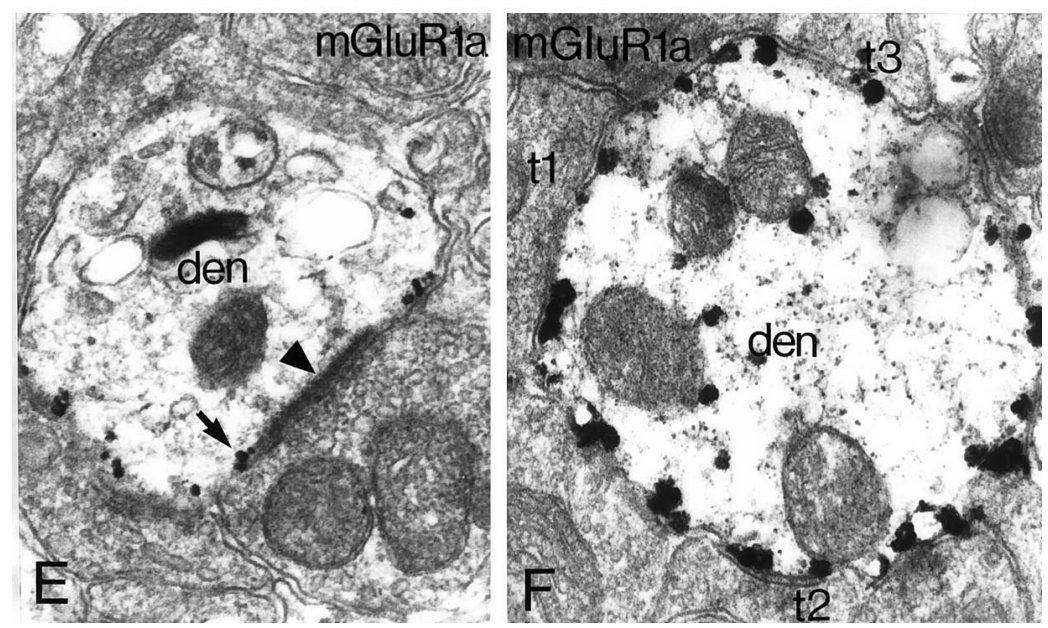

many hours for new receptors to be synthesized and transported from the cell body to the plasma membrane, it would only require minutes for a prefabricated pool of receptors to be inserted into the membrane (Szekeres et al., 1998). Rubio and Wenthold (1999) recently showed that there is a selective distribution of intracellular ionotropic glutamate receptor subunits and mGluR1a with respect to their cellular location, i.e., apical versus basilar dendritic regions in dorsal cochlear neurons. They concluded that the distribution of intracellular receptors was related to that of synaptic receptors and that there was no evidence for a pool of intracellular receptors that function as a receptor reserve near the postsynaptic densities. It is difficult to extrapolate these data to the SNr because GABAergic and glutamatergic synapses are homogeneously distributed along proximal and distal dendrites of SNr neurons (Shink and Smith, 1995; Smith et al., 1998).

In any case, it is clear that a difference exists in the mGluR1a and mGluR5 regulatory systems that makes these two receptor subtypes differentially distributed on the plasma membrane of SN neurons. It is noteworthy that similar findings were obtained in the monkey pallidum (Hanson and Smith, 1999). Interestingly, the pattern of subcellular distribution of the two group I mGluRs described in the present study is consistent with recent in vitro electrophysiological data showing that specific antagonists of mGluR1, but not mGluR5, abolish slow EPSPs in rat SNr neurons 


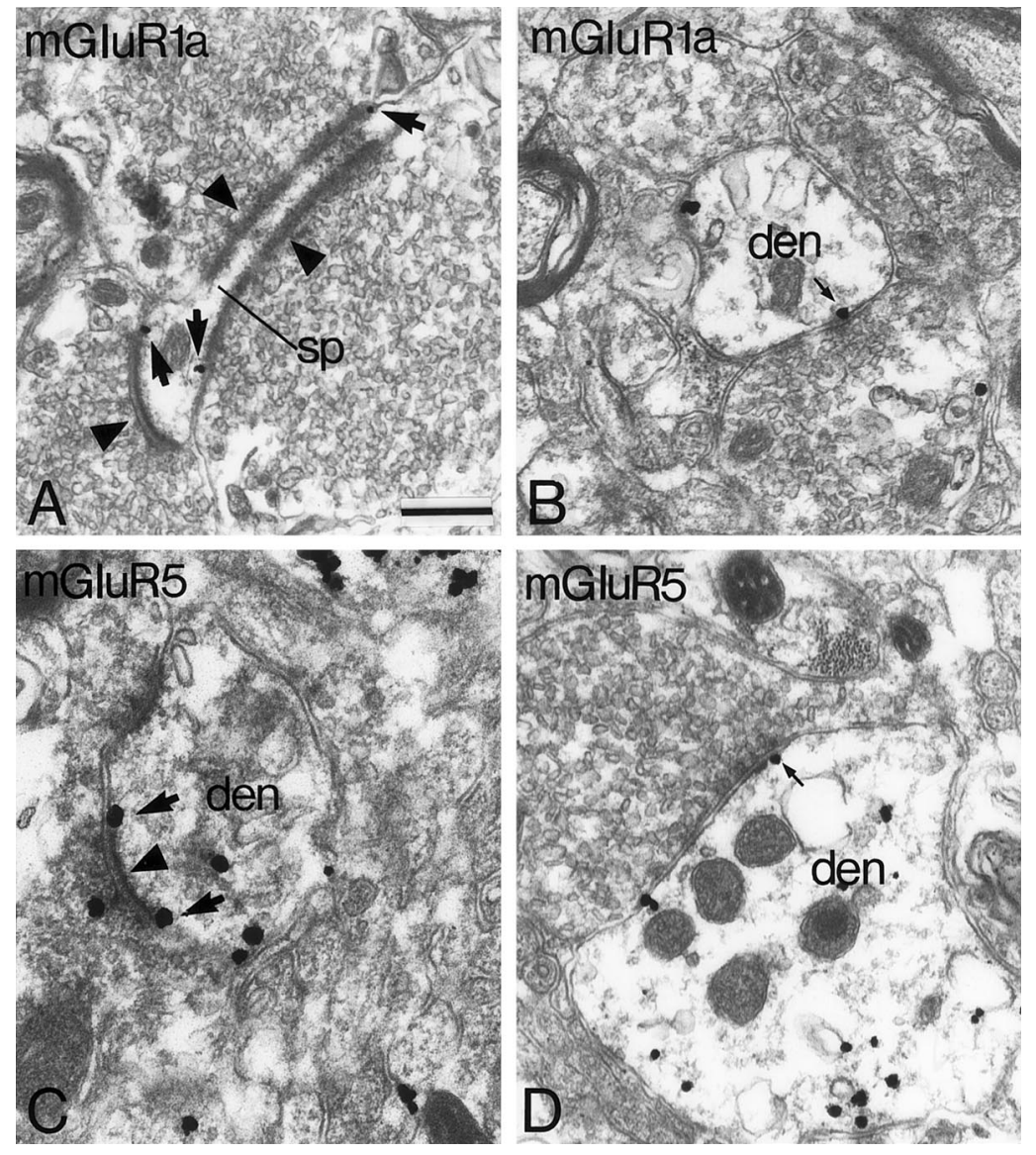

Figure 6. Subsynaptic localization of Group I mGluRs in the monkey SNc. $A$, mGluR1a-immunoreactive gold particles (large arrows) perisynaptic to three asymmetric postsynaptic specializations (arrowheads). B, A mGluR1aimmunoreactive gold particle (small arrow) in the main body of a symmetric synapse. $C$, mGluR5 immunoreactivity (large arrows) perisynaptic to an asymmetric axodendritic synapse (arrowhead). D, mGluR5 immunoreactivity (small arrow) in the main body of a symmetric synapse. Scale bar, $0.25 \mu \mathrm{m}$ (valid for $B-D$ ).
(Marino et al., 1999). Additional studies of the stimuli that are sufficient to cause mGluR5 receptors to be inserted into the plasma membrane and a better characterization of the differential roles played by the two group I mGluRs should help to explain the functional importance of these anatomical observations.

\section{Group I mGluRs at symmetric GABAergic synapses}

Our data showed that most of the plasma membrane-bound immunogold particles are either extrasynaptic or located in the main body of putative GABAergic synapses in rat and monkey SNr neurons. Although GABA immunostaining was not used to characterize the neurotransmitter content of the presynaptic boutons at these synapses, their ultrastructural features and pattern of innervation are consistent with those of striatal terminals described in previous studies (Smith et al., 1998). The pattern of group I mGluR distribution in the $\mathrm{SN}$ is strikingly different from that of group I mGluRs in the cerebellum and hippocampus in which both mGluR1a and mGluR5 are perisynaptic to asymmetric synapses without any significant association with symmetric synapses (Baude et al., 1993; Nusser et al., 1994; Lujan et al., 1996; Hanson and Smith, 1999). However, group I mGluR labeling at symmetric striatal synapses was also found in the monkey globus pallidus (Hanson and Smith, 1999), which indicates that postsynaptic mGluRs are associated with striatal synapses in the two major output structures of the basal ganglia. A potential explanation for this labeling is that mGluR1a and mGluR5 antibodies used in this study cross-react with GABA-B receptors that were also found to be expressed at striatonigral synapses in monkeys (Smith et al., 2000). However, this is unlikely because the synthetic peptides used to generate both group I mGluR antisera have no significant homologies with the amino acid sequence of GABA-B receptor subtypes (Kaupmann et al., 1997, 1998; White et al., 1998). Furthermore, both group I mGluR antisera label a single band corresponding to the molecular weight of mGluR1a and mGluR5 in Western blots (Testa et al., 1998; Upstate Biotechnology). Together, these data indicate that there is a clear ordering of postsynaptic group I mGluRs at symmetric striatonigral synapses. It is noteworthy that a mismatch between receptor localization and neurotransmitter release is not unique to group I mGluRs. Similar findings were obtained in the rat cerebellum in which GABA-A receptor subunits coexist with AMPA receptors in glutamatergic mossy fiber synapses (Nusser et al., 1998). Clarke and Bolam (1998) also showed that the AMPA GluR2/3 subunits are expressed at GABAergic pallidosubthalamic synapses in rats.

One could hypothesize that Group I mGluRs are expressed at GABAergic synapses to specifically modulate the functioning of GABA receptors. Although such interactions have not yet been studied in detail, modulation of IPSPs after group I mGluR activation was demonstrated in various brain regions, including the rat substantia nigra (Glaum and Miller, 1993; Bonci et al., 1997; Morishita et al., 1998). On the basis of recent data showing that activation of the metabotropic D5 dopamine receptors inhibits the function of GABA-A receptors via direct proteinprotein interactions (Liu et al., 2000), it is possible that such mechanisms can also be involved in mediating interactions between group I mGluRs and GABA-A receptor subunits at striatal synapses.

Because a relatively small proportion of nigral afferents are 


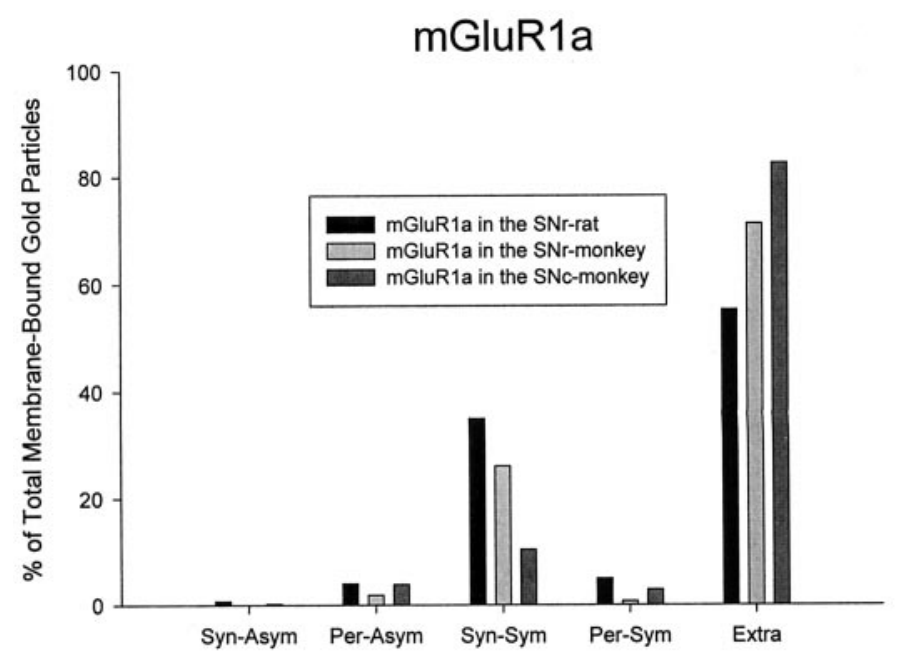

mGluR5

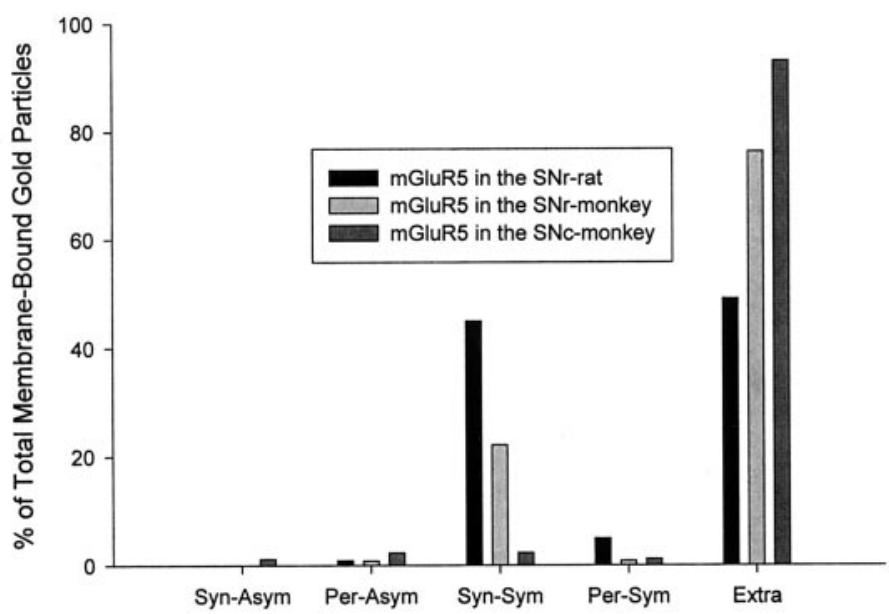

Figure 7. Relative subsynaptic distribution of plasma membrane-bound mGluR1a- and mGluR5-immunoreactive gold particles in the $\mathrm{SNr}$ and $\mathrm{SNc}$ of rat and monkey. Note that the bulk of mGluR1a and mGluR5 immunoreactivity is extrasynaptic. Number of gold particles $(n)$ and dendrites (den) examined: mGluR1a in monkey SNc $(n=662$, den $=$ 230); mGluR1a in monkey $\mathrm{SNr}(n=963$, den $=178)$; mGluR5 in monkey SNc $(n=834$, den $=227)$; mGluR5 in monkey SNr $(n=653$, den $=200)$; mGluR1a in rat $\mathrm{SNr}(n=400$, den $=81)$; mGluR5 in rat $\mathrm{SNr}(n=230$, den $=127)$. Syn-Asym, Synaptic in relation to an asymmetric synapse; Per-Asym, perisynaptic to an asymmetric synapse; Syn-Sym, synaptic to a symmetric synapse; Per-Sym, perisynaptic to an asymmetric synapse; Extra, extrasynaptic.

glutamatergic (Smith et al., 1998), the source of the transmitter that activates group I mGluRs remains uncertain. As discussed in our previous study (Hanson and Smith, 1999), three possibilities should be considered: (1) extrasynaptic diffusion of glutamate from subthalamonigral synapses (Asztely et al., 1997; Barbour and Hausser, 1997), (2) release of glutamate from astrocytes (Antanitus, 1998; Araque et al., 1999), and (3) corelease of GABA and glutamate from striatonigral terminals (Dubinsky, 1989; White et al., 1994).

The extrasynaptic localization of G-protein-coupled receptors is a general phenomenon in the CNS (Yung et al., 1995; Gracy et al., 1997; Dournaud et al., 1998; Bernard et al., 1999). Although the functions and mechanisms of activation of these receptors still remain to be established, their pattern of distribution indicates that they may play much more subtle and complex modulatory functions in neuronal activity than previously thought.

\section{REFERENCES}

Abe T, Sugihara H, Nawa H, Shigemoto R, Mizuno N, Nakanishi S (1992) Molecular characterization of a novel metabotropic glutamate receptor mGluR5 coupled to inositol phosphate/ $\mathrm{Ca}^{2+}$ signal transduction. J Biol Chem 267:13361-13368.

Antanitus DS (1998) A theory of cortical-astrocyte interaction. The Neuroscientist 4:154-159.

Araque A, Parpura V, Sanzgiri RP, Haydon PG (1999) Tripartite synapses: glia, the acknowledged partner. Trends Neurosci 22:208-215.

Asztely F, Erdemli G, Kullmann DM (1997) Extrasynaptic glutamate spillover in the hippocampus: dependence on temperature and the role of active glutamate uptake. Neuron 18:281-293.

Barbour B, Hausser M (1997) Intersynaptic diffusion of neurotransmitter. Trends Neurosci 20:377-384.

Baude A, Nusser Z, Roberts JDB, Mulvihill E, McIlhinney RAJ, Somogyi P (1993) The metabotropic glutamate receptor (mGluR1 alpha) is concentrated at perisynaptic membrane of neuronal subpopulations as detected by immunogold reaction. Neuron 11:771-787.

Bernard V, Laribi O, Levey AI, Bloch B (1998) Subcellular redistribution of $\mathrm{m} 2$ muscarinic acetylcholine receptors in striatal interneurons in vivo after acute cholinergic stimulation. J Neurosci 18:10207-10218.

Bernard V, Levey AI, Bloch B (1999) Regulation of the subcellular distribution of $\mathrm{m} 4$ muscarinic acetylcholine receptors in striatal neurons in vivo by the cholinergic environment: evidence for regulation of cell surface receptors by endogenous and exogenous stimulation. J Neurosci 19:10237-10249.

Berthele A, Laurie DJ, Platzer L, Zieglglansberger W, Tolle TR, Sommer B (1998) Differential expression of rat and human type I metabotropic glutamate receptor splice variant messenger RNAs. Neuroscience 85:733-749.

Bolam JP, Smith Y (1990) The GABA and substance P input to dopaminergic neurones in the substantia nigra of the rat. Brain Res 529:57-78.

Bonci A, Grillner P, Siniscalchi A, Mercuri NB, Bernardi G (1997) Glutamate metabotropic receptor agonists depress excitatory and inhibitory transmission on rat mesencephalic principal neurons. Eur J Neurosci 9:2359-2369.

Brakeman PR, Lanahan AA, O'Brien R, Roche K, Barnes CA, Huganir RL, Worley PF (1997) Homer: a protein that selectively binds metabotropic glutamate receptors. Nature 386:284-288.

Ciruela F, Soloviev MM, McIlhenney RAJ (1999) Co-expression of metabotropic glutamate receptor type 1a with Homer 1a/Vesl-1S increases the cell surface expression of the receptor. Biochem $\mathrm{J}$ 341:795-803.

Clarke NP, Bolam JP (1998) Distribution of glutamate receptor subunits at neurochemically characterized synapses in the entopeduncular nucleus and subthalamic nucleus of the rat. J Comp Neurol 397:403-420.

Conn PJ, Pin J-P (1997) Pharmacology and functions of metabotropic glutamate receptors. Annu Rev Pharmacol Toxicol 37:205-237.

Dournaud P, Boudin H, Schonbrunn A, Tannenbaum GS, Beaudet A (1998) Interrelationships between somatostatin sst2A receptors and somatostatin-containing axons in rat brain: evidence for regulation of cell surface receptors by endogenous somatostatin. J Neurosci 18:1056-1071.

Dubinsky JM (1989) Development of inhibitory synapses among striatal neurons in vitro. J Neurosci 9:3955-3965.

Dumartin B, Caille I, Gonon F, Bloch B (1998) Internalization of D1 dopamine receptor in striatal neurons in vivo as evidence of activation by dopamine agonists. J Neurosci 18:1650-1661.

Fiorello CD, Williams JT (1998) Glutamate mediates an inhibitory postsynaptic potential in dopamine neurons. Nature 394:78-82.

Glaum SR, Miller RJ (1993) Activation of metabotropic glutamate receptors produces reciprocal regulation of ionotropic glutamate and GABA responses in the nucleus of the tractus solitarius of the rat. J Neurosci 13:1636-1641.

Gracy KN, Svingos AL, Pickel VM (1997) Dual ultrastructural localization of $\mu$-opioid receptors and NMDA-type glutamate receptors in the shell of the rat nucleus accumbens. J Neurosci 17:4839-4848.

Greengard P, Allen PB, Nairn AC (1999) Beyond the dopamine receptor: the DARPP-32/protein phosphatase-1 cascade. Neuron 23:435-447.

Grofova I, Rinvik E (1970) An experimental electron microscopic study on the striatonigral projection in the cat. Exp Brain Res 11:249-262.

Hajdu F, Hassler R, Bak IJ (1973) Electron microscopic study of the substantia nigra and the strio-nigral projection in the rat. Z Zellforschung Mikroskop Anat 146:207-221.

Hanson JE, Smith Y (1999) Group I metabotropic glutamate receptors at GABAergic synapses in monkeys. J Neurosci 19:6488-6496.

Houamed KM, Kuijper JL, Gilbert TL, Haldeman BA, O'Hara PJ, Mulvihill ER, Almers W, Hagen FS (1991) Cloning, expression, and 
gene structure of a $\mathrm{G}$ protein-coupled glutamate receptor from rat brain. Science 252:1318-1321.

Hubert GW, Smith Y (1999) Subsynaptic localization of group I metabotropic glutamate receptors in the ventral midbrain of rats. Soc Neurosci Abstr 25:468.10.

Kaupmann K, Huggel K, Heid J, Flor PJ, Bischoff S, Mickel SJ, McMaster G, Angst C, Bittiger H, Froestl W, Bettler B (1997) Expression cloning of $\mathrm{GABA}(\mathrm{B})$ receptors uncovers similarity to metabotropic glutamate receptors. Nature 386:239-246.

Kaupmann K, Malitschek B, Schuler V, Heid J, Froestl W, Beck P, Mosbacher J, Bischoff S, Kulik A, Shigemoto R, Karschin A, Bettler B (1998) GABA(B)-receptor subtypes assemble into functional heteromeric complexes. Nature 396:683-687.

Kosinski CM, Standaert DG, Testa CM, Penney JB, Young AB (1998) Expression of metabotropic glutamate receptor 1 isoforms in the substantia nigra pars compacta of the rat. Neuroscience 86:783-798.

Lissin DV, Carroll RC, Nicoll RA, Malenka RC, von Zastrow M (1999) Rapid, activation-induced redistribution of ionotropic glutamate receptors in cultured hippocampal neurons. J Neurosci 19:1263-1272.

Liu F, Wan Q, Pristupa ZB, Yu XM, Wang YT, HB Niznik (2000) Direct protein-protein coupling enables cross-talk between dopamine D5 and gamma-aminobutyric acid A receptors. Nature 403:274-280.

Liu M, Kirchgessner AL (2000) Agonist- and reflex-evoked internalization of metabotropic glutamate receptor 5 in enteric neurons. J Neurosci 20:3200-3205.

Lujan R, Nusser Z, Roberts JDB, Shigemoto R, Somogyi P (1996) Perisynaptic location of metabotropic glutamate receptors mGluR1 and mGluR5 on dendrites and dendritic spines in the rat hippocampus. Eur J Neurosci 8:1488-1500.

Mantyh PW, Allen CJ, Ghilardi JR, Rogers SD, Mantyh CR, Liu H, Bausbaum AI, Vigna SR, Maggio JE (1995) Rapid endocytosis of a G protein-coupled receptor: substance P-evoked internalization of its receptor in the rat striatum in vivo. Proc Natl Acad Sci USA 92:2622-2626.

Marino MJ, Bradley SR, Wittmann M, Conn PJ (1999) Direct excitation of GABAergic projection neurons of the rat substantia nigra pars reticulata by activation of the mGluR1 metabotropic glutamate receptor. Soc Neurosci Abstr 25:446.

Meltzer LT, Serpa KA, Christoffersen CL (1997) Metabotropic glutamate receptor-mediated inhibition and excitation of substantia nigra dopamine neurons. Synapse 26:184-193.

Minakami R, Katsuki F, Sugiyama H (1993) A variant of metabotropic glutamate receptor subtype 5: an evolutionally conserved insertion with no termination codon. Biochem Biophys Res Commun 194:622-627.

Morishita W, Kirov SA, Alger BE (1998) Evidence for metabotropic glutamate receptor activation in the induction of depolarizationinduced suppression of inhibition in hippocampal CA1. J Neurosci 18:4870-4882.

Nusser Z, Mulvihill E, Streit P, Somogyi P (1994) Subsynaptic segregation of metabotropic and ionotropic glutamate receptors as revealed by immunogold localization. Neuroscience 61:421-427.

Nusser Z, Sieghart W, Somogyi P (1998) Segregation of different $\mathrm{GABA}_{\mathrm{A}}$ receptors to synaptic and extrasynaptic membranes of cerebellar granule cells. J Neurosci 18:1693-1703.
Ottersen OP, Landsend AS (1997) Organization of glutamate receptors at the synapse. Eur J Neurosci 9:2219-2224.

Phillips T, Rees S, Augood S, Waldvogel H, Faujli R, Svendsen C, Emson $P$ (2000) Localization of metabotropic glutamate receptor type 2 in the human brain. Neuroscience 95:1139-1156.

Reynolds ES (1963) The use of lead citrate at high $\mathrm{pH}$ in an electron opaque stain in electron microscopy. J Cell Biol 17:208-212.

Roche KW, Tu JC, Petralia RS, Xiao B, Wenthold RJ, Worley PF (1999) Homer $1 \mathrm{~b}$ regulates the trafficking of group I metabotropic glutamate receptors. J Biol Chem 274:25953-25957.

Rubio ME, Wenthold RJ (1999) Differential distribution of intracellular glutamate receptors in dendrites. J Neurosci 19:5549-5552.

Shink E, Smith Y (1995) Differential synaptic innervations of neurons in the internal and external segments of the globus pallidus by the GABAand glutamate-containing terminals in the squirrel monkey. J Comp Neurol 358:119-141.

Smith Y, Bolam JP (1991) Convergence of synaptic inputs from the striatum and the globus pallidus onto identified nigrocollicular cells in the rat: a double anterograde labeling study. Neuroscience 44:45-73.

Smith Y, Charara A, Parent A (1996) Synaptic innervation of midbrain dopaminergic neurons by glutamate-enriched terminals in the squirrel monkey. J Comp Neurol 364:231-253.

Smith Y, Bevan MD, Shink E, Bolam JP (1998) Microcircuitry of the direct and indirect pathways of the basal ganglia. Neuroscience $86: 353-387$

Smith Y, Charara A, Hanson JE, Paquet M, Levey AI (2000) GABAB and group I metabotropic glutamate receptors in the striatopallidal complex in primates. J Anat 196:555-576.

Szekeres PG, Koenig JA, Edwardson JM (1998) Involvement of receptor cycling and receptor reserve in resensitization of muscarinic responses in SH-SY5Y human neuroblastoma cells. J Neurochem 70:1694-1703.

Testa CM, Standaert DG, Young AB, Penney Jr JB (1994) Metabotropic glutamate receptor mRNA expression in the basal ganglia of the rat. J Neurosci 14:3005-3018.

Testa CM, Friberg IK, Weiss SW, Standaert DG (1998) Immunohistochemical localization of metabotropic glutamate receptors mGluR1a and mGluR2/3 in the rat basal ganglia. J Comp Neurol 390:5-19.

White JH, Wise A, Main MJ, Green A, Fraser NJ, Disney GH, Barnes AA, Emson P, Foord SM, Marshall FH (1998) Heterodimerization is required for the formation of a functional $\mathrm{GABA}_{\mathrm{b}}$ receptor. Nature 396:679-682.

White LE, Hodges HD, Carnes KM, Price JL, Dubinsky JM (1994) Colocalization of excitatory and inhibitory neurotransmitter markers in striatal projection neurons in the rat. J Comp Neurol 339:328-340.

Wichmann T, DeLong MR (1998) Models of basal ganglia function and pathophysiology of movement disorders. Neurosurg Clin N Am 9:223-236.

Wigmore MA, Lacey MG (1998) Metabotropic glutamate receptors depress glutamate-mediated synaptic input to rat midbrain dopamine neurones in vitro. Br J Pharmacol 123:667-674.

Yung KK, Bolam JP, Smith AD, Hersch SM, Ciliax BJ, Levey AI (1995) Immunocytochemical localization of D1 and D2 dopamine receptors in the basal ganglia of the rat: light and electron microscopy. Neuroscience 65:709-730. 